\title{
Analyses of the
}

\section{Competitiveness of Forest Industry in the Republic of} Macedonia

Nenad Savić

younger researcher, Foper II

\author{
Makedonka Stojanovska \\ University St. "Kiril and Metodij"- \\ Faculty of forestry, Skopje \\ makedonka@sf.ukim.edu.mk
}

Vladimir Stojanovski

PhD student, BOKU, Wien

\section{Abstract}

Background and purpose: This paper gives a thorough picture of the competitiveness characteristics of the Macedonian forest based industry for the period 1993 to 2006, from its independence to present times. The main purpose of this study is to analyze competitiveness of Macedonian forest industry and the factors that influences the creation and development of competitive advantages.

Material and methods: The study is based on theoretical tool of the Porter 's "diamond" model of the national competitiveness using four linked factors like: factor conditions, demand factor, firm's strategy, rivalry and structure and the forth one, related and supported industries. The method used is case study which includes collection of quantitative data, gathered through documentation, archival records, academic literature, publications, journals and websites.

Results and Conclusion: The analyzes has shown that the main strengths of Macedonian forest based industry are due to the existence of favorable factor conditions, as a cheap labor and energy cost-compared with region, good geographic location and relatively decent transport infrastructure. Weaknesses come from the lack of infrastructural investments (lack of capital), inappropriate management strategies, outdated machinery, low productivity and low value added products. To achieve better results industry should be organised in a better way and further investments in modern technologies and human resources are necessary.

Key words: forest industry, competitiveness, demand, firm condition, national market

\section{INTRODUCTION}

The competitiveness issue is a crucial element of interest for all governments, industries and economies that work under the principles of market economy. To be competitive and to stay at that position requires constant adjustments to market conditions, following the competitors and trends, but first of all, there is a need for restructuring the main production characteristics as quality, standard and prices according to the demand of the domestic and the international market. This study is one of the first attempts in Macedonia to present accumulated statistical material and analyze them with modern methods and approaches used in leading countries for assessing economic and industrial development.

It is important to know what are the main characteristics that can hold the sectors to be competitive, and what are the problematic areas that have to be taken into consideration to keep the sectors' competitive position. All of these questions are included and observed by this analysis, through the application of specifically chosen quantitative methods.

The main purpose of this study is to analyze competitiveness of Macedonian forest industry and the factors that influences the creation and development of competitive advantages using Porter's Theory of Competitive Advantage of Nations [1]. To meet this aim, several objectives and research questions are answered:

- to gather information's about current situation of forest industry in Macedonia,

- to analyze wood products market and current status of forest industry and

- to achieve a deeper understanding of competitive position and appraise level of competitiveness of Macedonian forest industry.

The research questions of this paper are:

1. What factors affect the competitiveness of forest sector in Republic of Macedonia?

2. What are main competitive advantages and disadvantages of Macedonian forest industry?

3. What recommendations could be given to Macedonian policy makers or managers of companies to enhance forest industry competitiveness? 


\section{MATERIALS AND METHODS}

This paper relies on quantitative methodology or applies extensive statistical data.

The materials used for a quantitative research were gathered from documentation, archival records, academic literature, publications, journals and websites.

Analyses of collected data was carried out in the framework of the Michael Porters "diamond" model of competitiveness [1].

The determinants were listed and collected data were categorized in 5 categories under positive and negative factors, in order to analyze the competitiveness of forest industry.

According to Porter [1], competitive advantage of nations is the outcome of 4 interlinked factors and activities in and between companies (Figure 1):

- Factor conditions. This category includes production factors such as natural resources and geographical location, as well as created factors inherited from preceding stages.

- Demand conditions. The demand is formed by two constituents: local (domestic) market, as a starting source, and export to the international markets, and shows the nature of demand for the industry's product or service.

- The Strategy, structure and rivalry of firms. Direct competition impels firms to work for increases in productivity and innovation, and motivate leading companies to invest in the product, management and marketing. The competitive pressure also motivates higher organizational efficiency and training. Firms have a variety of structures and strategies to use, and that some will be more effective than others.

- Related and supporting industries. Spatial proximity of upstream or downstream industries facilitates the exchange of information and promotes a continuous exchange of ideas and innovations.

M. Porter model offers two additional areas from which companies can draw competitive advantages: chance which reflect rapid changes on world financial markets, unexpected growth in local orinternational growth, wars etc; and influence of Government through its policies as a catalyst and challenger; it's role is to encourage - or even push - companies to raise their aspirations and move to higher levels of competitive performance (Figure 1).

Namely, the "diamond" model is a mutually reinforcing system in which the role of any determinant cannot be isolated and the effect of one determinant is closely dependent with the others. Advantage in every determinant is not prerequisite for competitive advantage, but the interplay of advantage in many determinants reinforces benefits that are extremely hard for rivals to nullify or replicate.

\section{RESULTS AND DISCUSSION}

The Republic of Macedonia is situated in the central part of the Balkan Peninsula. It covers an area of 25 $713 \mathrm{~km}^{2}$ and has a population of 2050000 . Forestry in Macedonia is an economy branch with minor participation in national Gross Domestic Product with 0.3$0.5 \%$, but if the multifunctional uses are valorized, the contribution will be much bigger. The contribution of the forest industry (primary and secondary wood processing, furniture, paper and celluloses...) in GDP is 2.5-3\% [2] and the share in total labor is $0.8 \%$ [3]. Total wooded land is 988000 ha or $39 \%$; forest area is 905653 ha or $36 \%$ of total area and other wooded land is around 78500 ha. According the forms of management, high forest are 262790 ha or $29 \%$, coppice 642863 or $71 \%$. The most abundant species are oak (Quercus spp.) and beech (Fagus spp.). Forest distribution by purpose is: Economic forests are 834347 ha (92\%), Protective 17617 ha (2\%) and National Parks 54036 ha (6\%). Growing stock is 74.3 million $\mathrm{m}^{3}$ or $70 \mathrm{~m}^{3} / \mathrm{ha} \mathrm{(in} \mathrm{2006)} \mathrm{(Table} \mathrm{1).}$

$88 \%$ of all forest in country are state owned, and are managed by Public Enterprise (PE) "Macedonian forests" and national parks are managed by separate public institutions. The remaining $12 \%$ of forest area are owned by private owners. Privately owned forests are scattered, fragmented and small in size. There are approximate 220000 plots of an average size of 0.4 ha owned by approximate 65000 households [2].

Macedonia is relatively small country with limited forest area, which demand careful planning, reforestation and harvesting procedures. Clear cutting is allowed, mainly in coppice forests. The certification of the forests does not exists yet. Illegal logging is a big problem; the approximate $8630 \mathrm{~m}^{3}$ in 2006 or $10 \%$ of total harvesting in the country is from illegal activities [5], but some sources [6] states that this percentage reaches $20-25 \%$.

Fuelwood accounts for approximately $82-85 \%$ of produced roundwood, industrial roundwood accounted for remaining $15-18 \%$ respectively. Fuelwood consumption is around $700000-750000 \mathrm{~m}^{3}$ annually, and mainly are covered by the domestic sources.

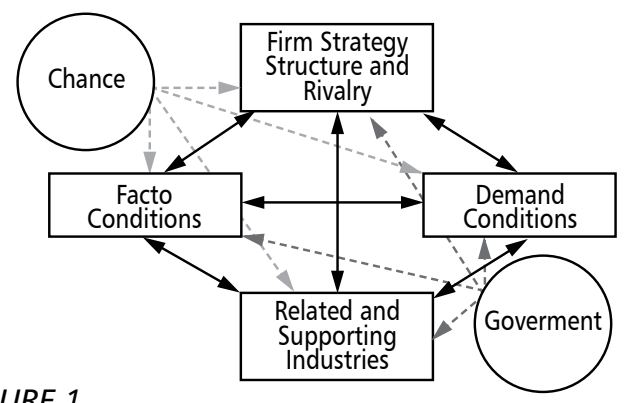

FIGURE 1

The Porter's Diamond system (source [1]) 
TABLE 1 Forest resources: area, growing stock and annual growth in 2006 (source [4])

\begin{tabular}{|c|c|c|c|c|}
\hline & Forest area & $\begin{array}{c}\text { Volume of growing } \\
\text { stock }\left(\mathrm{m}^{3}\right)\end{array}$ & $\begin{array}{c}\text { Total annual growth } \\
\left(\mathrm{m}^{3}\right)\end{array}$ & $\begin{array}{c}\text { Annual increment } \\
\left(\mathrm{m}^{3} / \mathrm{ha}\right)\end{array}$ \\
\hline Coppice & 642863 & 27000000 & 923860 & 1.44 \\
\hline High forests & 262790 & 46000000 & 906140 & 3.45 \\
\hline Total & 905653 & 74000000 & 1830000 & 2.02 \\
\hline
\end{tabular}

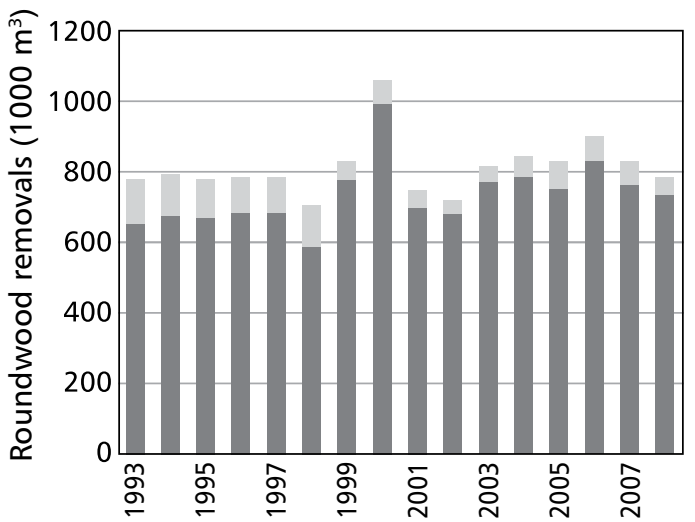

FIGURE 2

Non-conifer conifer

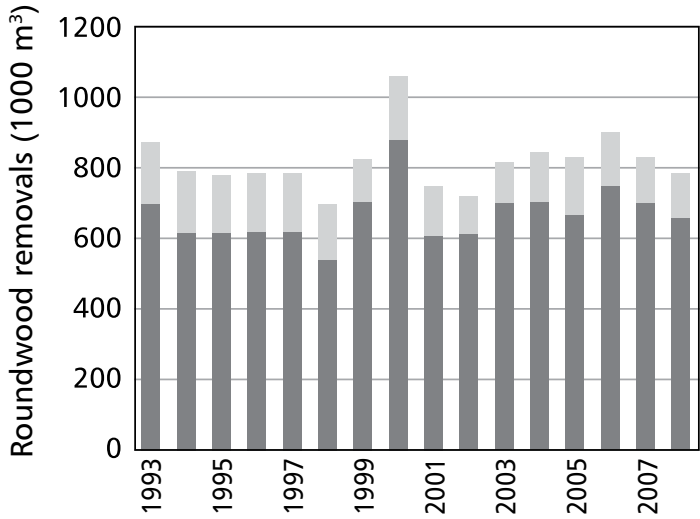

Fuel wood Industrial roundwood

Roundwood removals by: a) species and b) category (1993-2008) (source [7, 8])

The basis raw material - unprocessed round wood is supplied from domestic production i.e. from PE "Macedonian forests" [6]. Broadleaves (mostly beech) sawn wood is the main category produced; the conifer sawnwood is imported. The biggest percentage of industrial roundwood is used for sawnwood and veneer logs (more then $90 \%$ ), and smaller quantities of pulpwood and for other industrial uses (Figure 3).

The production of plywood and veneer is symbolic, and production of chip-board and fibreboard does not exist at all, so that the furniture industry imports them.

The main characteristic of the Macedonian labour market is high percentage of unemployment and comparing to the European labour market relatively cheap labour force [9] (Figure 4).

Forestry and forest industry plays an important role in the national economy especially in the rural areas because it provides employments for the rural population. According to statistics about 7000 people are directly employed by the forestry and forest industry sector. Indirectly the sector provides job opportunities (part-time jobs) to additional 35000 - 40000 people through multiplier effects. Tens of thousands of people rely on the forest industry for a living. As $40 \%$ of the population lives in rural areas and since a high proportion of these people are unemployed, forestry is likely to be of particular importance in raising living standards in rural areas [4].

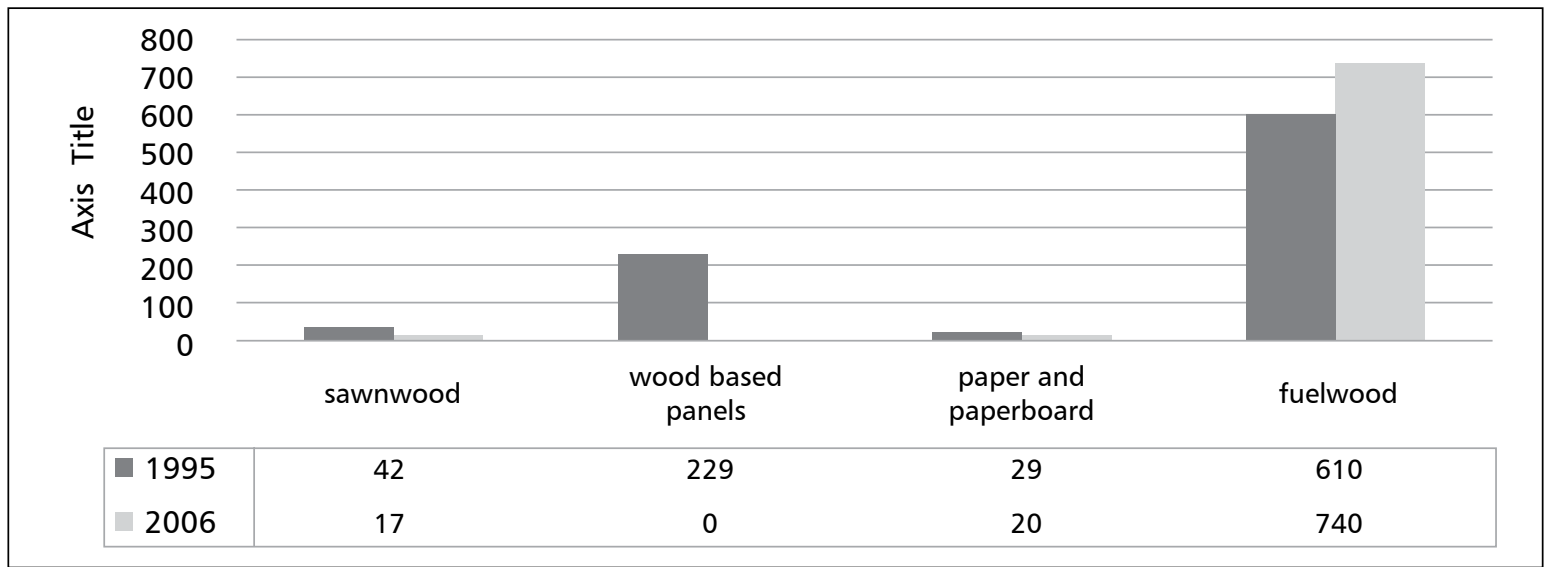




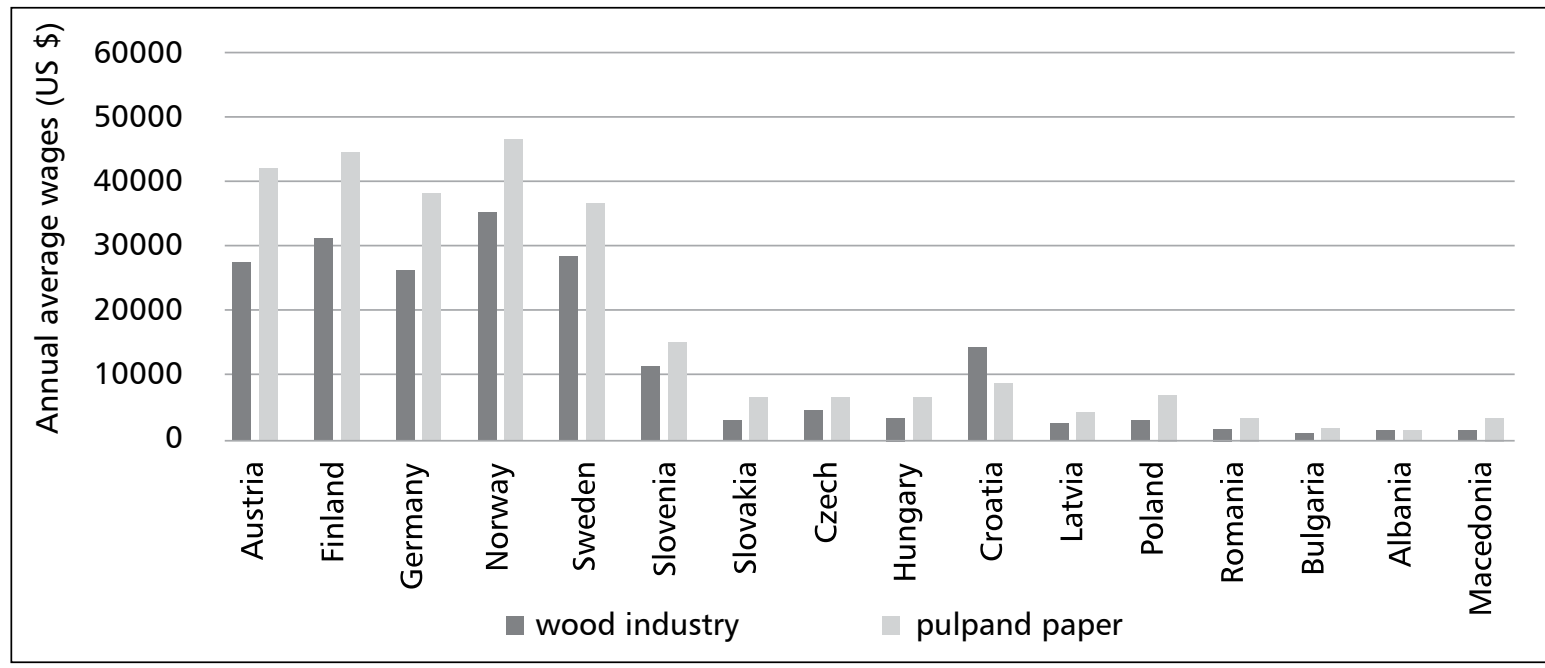

FIGURE 4

Annual average wages in forest industry in selected European countries in 2005 (US dollars) (source [9])

TABLE 2

Employment in forest sector in Macedonia (1994-2006) (source [4])

\begin{tabular}{|c|c|c|c|c|c|c|c|c|c|c|c|c|c|}
\hline $\begin{array}{c}\text { number of } \\
\text { workers }\end{array}$ & 1994 & 1995 & 1996 & 1997 & 1998 & 1999 & 2000 & 2001 & 2002 & 2003 & 2004 & 2005 & 2006 \\
\hline Forestry & 3592 & 3385 & 3767 & 3528 & 3401 & 3375 & 3000 & 2980 & 2830 & 2553 & 2940 & 2549 & 2517 \\
\hline Wood industry & 1456 & 1463 & 1079 & 1232 & 1957 & 1633 & 1224 & 1348 & 1076 & 1348 & 2634 & 2861 & 3199 \\
\hline $\begin{array}{c}\text { Pulp and } \\
\text { paper industry }\end{array}$ & 1694 & 1750 & 1208 & 1200 & 1265 & 1344 & 1337 & 1312 & 1235 & 1248 & 1766 & 1438 & 1734 \\
\hline Total & 6742 & 6598 & 6054 & 5960 & 6623 & 6352 & 5561 & 5640 & 5141 & 5149 & 7340 & 6848 & 7450 \\
\hline
\end{tabular}

Macedonia is mainly import oriented country with huge and growing trade deficit and relies on import of high value added wood products.
The external trade balance in the exchange of wood products is negative. The import value is several times bigger than the value of realized export. According

TABLE 3

Wood products net trade in Macedonia in 1000 US \$ (1996-2006) (source [7, 8])

\begin{tabular}{|c|c|c|c|c|c|c|c|c|c|c|c|}
\hline Years & 1996 & 1997 & 1998 & 1999 & 2000 & 2001 & 2002 & 2003 & 2004 & 2005 & 2006 \\
\hline $\begin{array}{c}\text { ROUND- } \\
\text { WOOD } \\
\text { Agg }\end{array}$ & -24 & -24 & 299 & 37 & -979 & 185 & 104 & 829 & 65 & 104 & 1222 \\
\hline $\begin{array}{c}\text { Fuelwood } \\
\text { Ind round- } \\
\text { wood }\end{array}$ & -21 & -21 & -21 & $-21,5$ & -910 & -234 & -245 & -25 & 90 & 137 & 171 \\
\hline $\begin{array}{c}\text { SAWN- } \\
\text { WOOD }\end{array}$ & 13673 & 13673 & -7772 & -9275 & -10860 & -4814 & -9416 & -9957 & -10868 & -9952 & -7755 \\
\hline $\begin{array}{c}\text { WOOD- } \\
\text { BASED } \\
\text { PANELS }\end{array}$ & 1285 & 554 & -8231 & -10947 & -10569 & -9384 & -12887 & -14784 & -19971 & -21526 & -24193 \\
\hline $\begin{array}{c}\text { WOOD } \\
\text { PULP }\end{array}$ & -2657 & -190 & -1437 & -635 & -1631 & -1171 & -415 & -373 & -204 & -372 & -960 \\
\hline $\begin{array}{c}\text { PAPER } \\
\text { AND } \\
\begin{array}{c}\text { PAPER- } \\
\text { BOARD }\end{array}\end{array}$ & -24300 & -46462 & -25926 & -42678 & -22434 & -22430 & -22428 & -33135 & -19850 & -19925 & -42400 \\
\hline TOTAL & -12047 & -32473 & -42769 & $-63461,5$ & -47452 & -37429 & -44938 & -56591 & -50763 & -51557 & -72864 \\
\hline
\end{tabular}


Macedonian State Statistical Office [4] in 2006 wood industry's export was 10 million dollars, and import \$ 83 million.

Subject who dominated the forestry in the country is PE "Macedonian forests" responsible for planning and executing forest operations, and is the largest supplier of raw material to forest industry. It also used to operate with seven sawmills with an annual capacity of $20000 \mathrm{~m}^{3}$ which are in process of privatization at the moment. In addition there is a great number (more then 500) of small and medium companies, mostly sawmills that operates on and off when saw logs can be acquired at affordable prices. Approximations are that more the 1000 firms existed in grey economy, but are impossible to establish the real number and assess their production results [10] (Table 4).

\section{TABLE 4}

Structure of enterprises in Republic of Macedonia in 2003 (source [10])

\begin{tabular}{|c|c|c|c|}
\hline & $\begin{array}{c}\text { Size of } \\
\text { enterprise }\end{array}$ & $\begin{array}{c}\text { Gross } \\
\text { output in } \\
\text { Euros }\end{array}$ & $\begin{array}{c}\text { Number of } \\
\text { enterprises }\end{array}$ \\
\hline \multirow{2}{*}{ Saw mills } & Small & 13556 & 549 \\
\cline { 2 - 4 } & Medium & 969 & 3 \\
\hline \multirow{2}{*}{$\begin{array}{c}\text { Wood } \\
\text { based } \\
\text { panels }\end{array}$} & Small & 477 & 10 \\
\cline { 2 - 4 } & Medium & & \\
\hline \multirow{2}{*}{$\begin{array}{c}\text { Paper and } \\
\text { paper- } \\
\text { board }\end{array}$} & Small & 15298 & 189 \\
\cline { 2 - 4 } & Medium & 3303 & 2 \\
\cline { 2 - 4 } & big & 10171 & 1 \\
\hline
\end{tabular}

Using Porter's diamond model, the factors affecting competitiveness of forest sector can be categorized as production factors, demand factors, firm strategy and industry structure, related and supporting industries and government related factors.

\section{Factors condition}

Macedonia has geographic location on the Central part of Balkan Peninsula, relatively close to the transport corridors (rail and roads) and access to big and lucrative markets in neighbourhood and Europe. (Italy, Greece, Austria, Germany, Serbia...). This good position which avail forest companies themselves to the low transport costs.

The country is relatively small in harvesting of forests. The use of forests and wood for industrial processes in Macedonia is at a modest level. As a consequence there is shortage of industrial timber and producers bear high costs and have low productivity. The high percent of low quality coppice forests, mainly beech and oak, (70\% of total forest area), many of which are highly degraded, together with the small quantity of conifers (around $10 \%$ of total growing stock), results in relatively low timber reserves, low timber mass, and low annual growth per unit of land. Macedonia has only $160000 \mathrm{~m}^{3}$ of annual harvest of industrial round wood. Quality of timber suffers because of lowyielding species, poor forest stands, and poor harvesting practices with limited access to the stands. Timber supply to local industry is inconsistent and uncertain especially to the small and medium size sawmills who are dependent of continuous supply and cannot afford delays in production.

Forest industry in Macedonia for the power mainly uses electrical energy. Regarding prices of electrical energy that industry is paying, compared from other countries in the region and EU is obvious that price of 4 Eurocents per kWh is relatively low and still very competitive.

Most of the equipment in use has been inhered from socialist era and dated from 90's. Machinery and equipment are outdated and inefficient (equipment in small sawmill companies is consist mainly of 1 or two band or circular saws, debarker, board lumber is dried on open air, very rarely in kiln), productivity is low, and there is lack of production process automation systems. Only a few individual small and private (furniture and sawn mills) companies have introduce some improvements in technology (as an automatic lathe's and laser guided saw), which does little to change the overall situation. As a consequences forest companies are faced with disadvantages as a wasteful use of raw materials and energy, high production losses, high power and raw material consumption, high pollution. Low investments in aging facilities leads toward low productivity and energy efficiency. All needed equipment and machinery have to be imported, because there aren't domestic producers in the country. The import is burdened with high prices on the international markets and transportation costs.

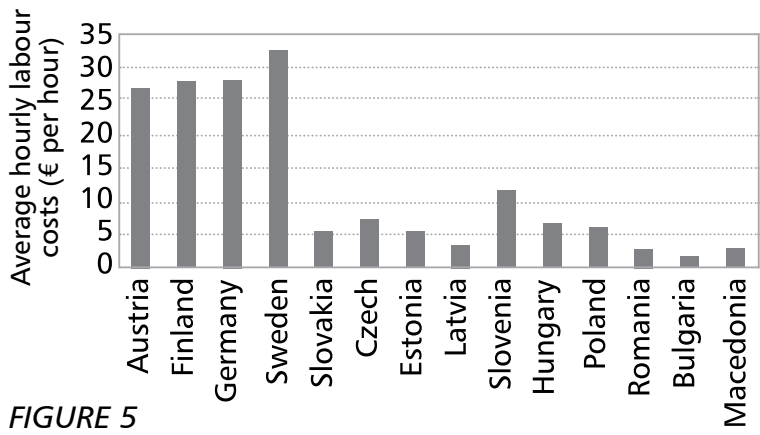

Average hourly labour costs in selected European countries in 2006 (in € per hour) (source [11, 4])

With average hourly labour costs of 2.63 Euro, wages in forest sector are well below average wages in EU countries [11,4], and this low cost of labor can bring comparative advantage (Figure 5).

Although basic factor conditions (forest resources abundance, geographical position, human resources) 
are on the modest level compared with other countries in the region, they still offer opportunities which should be further developed by improving the advanced factors (knowledge, capital availability, and infrastructure). Under M. Porter's theory [1] the important factor behind competitiveness of any industry is its human potential, skills and qualifications.

Impeding factors are: low quality of local raw materials and shortage of industrial timber. State property of forest resources is also impeding factor. PE "Macedonian forests" has unregulated and monopolistic position in supplying forest industry with raw materials, which supply is inconsistent and uncertain.

Forest industry is faced with shortage of modern equipment and automation systems which are not produced in the country. Level of investments is very low, especially in foreign direct investments (According Central Bank of Macedonia [12], FDI in wood industry in 2006 was only 4759000 \$US). Companies mainly finance themselves from their own and limited sources or from short term bank loans with high interest rate, which is insufficient to reach competitiveness needed for international markets. Numbers of innovations are very low, and collaborations with Forest faculty and other research institutions are negligible.

With investments in innovations, training, education, research and development, and in establishing the good relations with Forest faculty in Skopje (as a leading education institution in forestry), the situation can be improved. Managers and engineers needed more practical knowledge in modern technologies, communication technologies, international standards and marketing as a precondition to overcome present situation of low motivation and bad work mentality of local labour force, disrupted relationships and lack of cooperation between companies and R\&D institutions.

\section{Demand factors}

Demand is formed by two constituents: domestic (local) and international (export) demand.

Nations gain competitive advantage in industries or in industry segments where the home demand gives local firms a clearer or earlier picture of buyer needs than foreign rivals can have. Local customers not only provide firms with a source of income, but they educate firms about customer needs and perceptions, so the local customer has much more influence over how products are designed, supported, and sold.

Macedonia with its relatively small population and small domestic market cannot offer possibilities to develop economy of scale. A major increase of the domestic market capacity would be impossible in the absence of the general growth of national economy, accompanied by a substantial increase of the per capita GDP. A major influence on demand relates to the non-industri- al demands on forests, particularly for fuelwood. Nonindustrial uses of timber, including fuelwood is reached $2 / 3$ of entire consumption in the country (Figure 6).

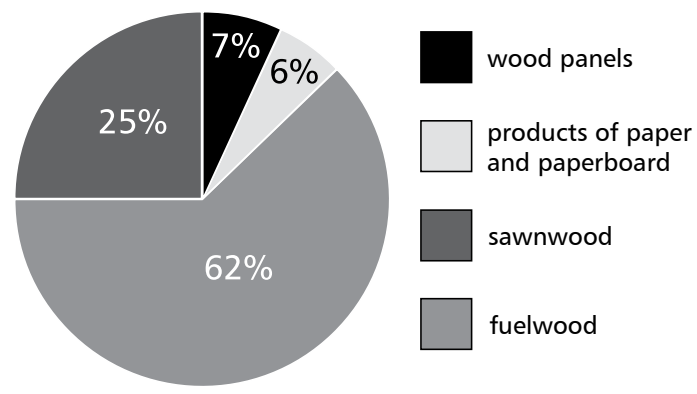

FIGURE 6

Structure of consumption of wood products (source $[7,8]$ )

Development of exports is burdened by low quality and low values added products, the underdeveloped infrastructure as well as the weak networks and almost non-existing cooperation between the companies. The firms in the wood industry do not have the technological capabilities, design and marketing skills, financial and business management, or related human resource capabilities, required to compete in the global market.

But despite this gloomy situation, international market offers a lot of opportunities, and wood industry in Macedonia can benefit and improve its competitiveness through export, and exploited lower labour cost compared with other countries.

\section{Firm's strategy, rivalry and structure}

As argued by Porter [1], domestic rivalry, like any rivalry, creates pressure on firms to improve and innovate. Local rivals push each other to lower costs, improve quality and service, develop new products and have role in innovation and the prospects for international success. Firms have a variety of structures and strategies to use, and that some will be more effective than others. Porter [1] asserts that national culture plays a significant role, in which structures and strategies are selected by management and relative success of these business models varies with each industry.

Regarding the structure, industry is dominated by the PE "Macedonian forests" who has monopolistic position on the market and is exclusive supplier to wood industry and large number of small sized private owned companies, with mainly domestic capital, although some of them have foreign capital, which main activity is sawnwood production. The existence of great numbers of sawmills is result of small starting capital needed and fast turnover of invested capital compared to production of other wood products. The private-operated firm developed fast, but because most of them have old fashion household management further development is limited. These companies are focused on 
the domestic market, and fierce rivalry exists among them. There is lack of horizontal and vertical integration, and concentration and cooperation is needed in order to increase size of companies and their ability to invest in new, modern facilities and development of competitive export oriented production.

The managers adopt flexible strategy oriented mainly on domestic market, where they can change production lines according with external conditions in the market.

This strategy enables them to adopt new product, or to change design and produce small series in relatively rapid response to the changed market demand. There are also many companies operating illegally in the environment of "grey economy", which does not fulfill their financial obligation.

This structure does not contribute to the development of wood industry and do not bring competitive advantage. There is absence of cluster organization, companies are too weak, without vertical and horizontal integration, with production which is not complaint with international standards, without export potential and orientation, and, therefore, limited possibilities to integrate into global manufacturing and supply networks. Still their flexible strategy and specialty enable them to make quick response to the changes of the external environment.

\section{Related and supporting industries}

Adequate related and supporting sector is able to provide the producers with extra competitive advantages, and opportunities to use the products or services offered by the companies within the related and supporting sectors. Existence of developed network of subcontractors and suppliers in a given region or country, makes it possible to offer more complex products and after sale service systems and turn out primary products with a higher value-added.

The main related and supporting sectors with forest industry are: Logistics; Energy; Processing Equipment Manufacture; Chemicals; Auxiliaries Manufacture; IT; Banking and Finance; Insurance; Business Consulting and Environmental Services.

Machinery and processing equipment, materials from chemical and auxiliaries needed for production such as ironwork, furniture cloth, varnish and paints for the Macedonian wood industry is mostly imported.

Information technologies which are necessity in modern production are just getting a foothold in the wood processing companies. One of the main reasons for slow IT implementation is lack of educated and training personal and limited capital for purchasing new hardware and software. Regarding bank and finance sector, very limited capital loans are allocated to the wood industry.

Companies faced difficulties to secure their working capital through bank loans, their assets are often not accepted as a collateral, and interest are very high. One must also note that a company's chances of securing a loan are hinged on the private connections of its managers, rather than on the company's financial situation.

Macedonian forest industry is not organized in clusters, and cannot benefit from related and supporting sectors as a source of competitive advantage, and explore possibility of early access to high quality and reliable supplies of essential components and materials, and from the cost advantages gained from the competitive local supplies.

\section{Influence of Government}

The role of government is above all to act as a catalyst and challenger; to encourage - or even push - companies to raise their aspirations and move to higher levels of competitive performance. Porter [1] asserts that the government can have a role in all determinants of national competitiveness, but that the role can be negative as well as positive and that its role will always be partial - not sufficient in itself to make a national industry competitive.

The government of Macedonia has not yet established an attractive business environment, very important for foreign direct investments. Government policies and activities in Macedonia do not seem to be addressing these problems effective. In the past wood industry (as other industries too) had the role of social service.

After the independence, Macedonia began a process of trade liberalization, which intensified during the second half of the 1990's. Republic of Macedonia concluded a series of Free Trade Agreements with the neighbouring countries and other traditional partners: Turkey, Serbia and Montenegro, Bulgaria, Croatia, Bosnia and Herzegovina, Ukraine, Albania, Moldova and Romania.

In 2007, Macedonia sign Central European Free Trade Agreement (CEFTA), for its further trade liberalization. Another agreement that Macedonian has ratified is the Agreement for stabilization and Association with EU, signed in 2001. It regulates trade aspects focused on increased trade liberalization between Macedonia and European Union. The country is also member WTO from 2003.

But aside these positive steps, the government role in the forest sector during the past period was insignificant, and not supportive, bureaucratic obstacles in the State ministries and institutions are still high. State institutions (Inspections) are not deeply involved in activities toward solving the problem with illegal companies which does not fulfill their financial obligation toward 
State, and have market advantage. Experience of developed countries shows that long-term and clearly stated policy helps to achieve impressive results on the world market. The results are summarized into the following table 5, according to the applied conceptual framework.

\section{CONCLUSIONS}

The study reveals that the Macedonian forest industry is virtually lacking any obvious competitive advantages to be developed without major investments in infrastructure, technology upgrading, $R \& D$, and professional training of personnel. To achieve competitive success, firms from the industry must possess a com- petitive advantage in the form of either lower costs or differentiated products that command premium prices.

To sustain advantage, firms must achieve more sophisticated competitive advantages over time, through providing higher-quality products and services or producing more efficiently.

It is important and necessary for the State to abandon its sporadic interference, concentrating on creating a favorable investment environment and on introducing regulations promoting conscientious and rational use of natural resources (especially since forests are one of the few renewable resources).

Table 5

Diamond model of competitiveness of Macedonian forest industry - summary

\begin{tabular}{|c|c|c|c|}
\hline \multirow{12}{*}{$\begin{array}{c}\text { FACTOR } \\
\text { CONDITIONS }\end{array}$} & \multirow{2}{*}{$\begin{array}{l}\text { Geographic } \\
\text { position }\end{array}$} & Strengths & $\begin{array}{l}\text { - Good geographic location close to the main transport corridors } \\
\text { - Short distance to main export markets (EU, Balkan countries) }\end{array}$ \\
\hline & & Weakness & - Regional instability \\
\hline & \multirow{2}{*}{$\begin{array}{c}\text { Human } \\
\text { resources } \\
\text { (labour force) }\end{array}$} & Strengths & $\begin{array}{l}\text { - Tradition and experience } \\
\text { - Cheap labour cost which lead toward lowest producer prices in the } \\
\text { region } \\
\text { - High social importance, employment and existence of large part of } \\
\text { rural population }\end{array}$ \\
\hline & & Weaknesses & $\begin{array}{l}\text { - Mentality and absence of willingness to accept changes and modern } \\
\text { way of production } \\
\text { - Senior managers and owners are not familiar with modern ways of } \\
\text { doing business }\end{array}$ \\
\hline & \multirow[b]{2}{*}{$\begin{array}{l}\text { Natural } \\
\text { resources }\end{array}$} & Strengths & - Wood as a renewable resource \\
\hline & & Weakness & $\begin{array}{l}\text { - Low quality of forest resources (high percents of hardwood coppice } \\
\text { stands) } \\
\text { - State property of forest resources }(90 \%) \\
\text { - Shortage of industrial timber } \\
\text { - Inconsistent and uncertain supply with raw materials } \\
\text { - Poor harvesting practice } \\
\text { - Illegal logging }\end{array}$ \\
\hline & Innovations & Weaknesses & $\begin{array}{l}\text { - Low investments in innovation } \\
\text { - Small firms have week ability to develop innovations }\end{array}$ \\
\hline & \multirow[b]{2}{*}{ Infrastructure } & Strengths & - $\quad$ Good transport infrastructure of road network \\
\hline & & Weaknesses & $\begin{array}{l}\text { - Low efficiency and out-of-date railway coaches } \\
\text { - Country do not have sea access, the closest port is Thessalonici in } \\
\text { Greece }\end{array}$ \\
\hline & Equipment & Weaknesses & $\begin{array}{l}\text { - Outdated and inefficient machinery leads toward high production } \\
\text { losses } \\
\text { - High consumption of energy per product } \\
\text { - Pollution }\end{array}$ \\
\hline & \multirow{2}{*}{ Energy supply } & \begin{tabular}{|l|} 
Strengths \\
\end{tabular} & - Low price of energy (compare with the region) \\
\hline & & Weaknesses & - Absence of long-term contracts with energy suppliers \\
\hline \multirow{4}{*}{$\begin{array}{l}\text { DEMAND } \\
\text { CONDITIONS }\end{array}$} & \multirow[b]{2}{*}{$\begin{array}{l}\text { Domestic } \\
\text { demands }\end{array}$} & Strengths & $\begin{array}{l}\text { - Flourishing furniture and construction industry as driving force } \\
\text { increase demand of forest products }\end{array}$ \\
\hline & & Weaknesses & $\begin{array}{l}\text { - Small size of domestic market } \\
\text { - GDP per capita is among the lowest in the region, so it is difficult to } \\
\text { have demanding and sophisticated home demand } \\
\text { - Bad relations between producers and buyers }\end{array}$ \\
\hline & \multirow[b]{2}{*}{$\begin{array}{l}\text { International } \\
\text { demands }\end{array}$} & Strengths & $\begin{array}{l}\text { - Trade liberalization agreements (CEFTA, Free Trade Agreements), } \\
\text { opportunity for further market expansion and export }\end{array}$ \\
\hline & & Weaknesses & $\begin{array}{l}\text { - Low quality of products and absence of certification of forest stands } \\
\text { limits export potentials } \\
\text { - Few high value-added products } \\
\text { - Production is not standardized } \\
\text { - At the same time trade liberalization -threat for domestic market } \\
\text { from new developing countries (China, India...) }\end{array}$ \\
\hline
\end{tabular}




\begin{tabular}{|c|c|c|c|}
\hline \multirow{5}{*}{$\begin{array}{l}\text { FIRM } \\
\text { STRATEGY, } \\
\text { STRUCTURE } \\
\text { AND } \\
\text { RIVALRY }\end{array}$} & Structure & Weaknesses & $\begin{array}{l}\text { - Monopolistic position of PE as a largest supplier of raw material to } \\
\text { forest industry } \\
\text { - Large number of private SME focused on domestic market } \\
\text { - Absence of cluster organization and lack of horizontal and vertical } \\
\text { integration }\end{array}$ \\
\hline & \multirow[b]{2}{*}{ Strategy } & Strengths & $\begin{array}{l}\text { SME adopt flexible strategy regarding production of small series of } \\
\text { new products }\end{array}$ \\
\hline & & Weaknesses & $\begin{array}{l}\text { - Fragmented and loosely connected companies with modest attempts } \\
\text { to cooperation in order to reach economy of scale } \\
\text { - Lack of modern business strategies, marketing and products design }\end{array}$ \\
\hline & \multirow[b]{2}{*}{ Rivalry } & Strengths & $\begin{array}{l}\text { - Fierce domestic competition creates pressure on firms to improve and } \\
\text { innovate }\end{array}$ \\
\hline & & Weaknesses & $\begin{array}{l}\text { - Disloyal competition of the unregistered firms (more then } 1000 \\
\text { estimated) } \\
\text { - The focus on the domestic market harm the competitiveness forest } \\
\text { industry on international markets }\end{array}$ \\
\hline \multirow{6}{*}{$\begin{array}{l}\text { RELATED AND } \\
\text { SUPPORTING } \\
\text { INDUSTRIES }\end{array}$} & $\begin{array}{l}\text { Machinery } \\
\text { supply }\end{array}$ & Weaknesses & - All machinery and equipment have to be import \\
\hline & $\begin{array}{l}\begin{array}{l}\text { Chemicals } \\
\text { and } \\
\text { Auxiliaries } \\
\text { supply }\end{array} \\
\end{array}$ & Weaknesses & $\begin{array}{l}\text { - Products such as ironwork, furniture cloth, varnish and paints are } \\
\text { also mainly from import. }\end{array}$ \\
\hline & \begin{tabular}{|c|} 
Relations with \\
educational \\
and R\&D \\
centers \\
\end{tabular} & Weaknesses & - Weak cooperation with forest faculty and other research institutions \\
\hline & \begin{tabular}{|l|} 
Information \\
technologies \\
\end{tabular} & Weaknesses & $\begin{array}{l}\text { - Very low implementation of IT technologies partly for the reason of } \\
\text { lack of capital, educated and training Personal }\end{array}$ \\
\hline & $\begin{array}{l}\text { Bank and } \\
\text { financial } \\
\text { sector }\end{array}$ & Weaknesses & $\begin{array}{l}\text { - Rigid and unstable bank credits (SME cannot obtain loans due to } \\
\text { high risk and high interest rates) } \\
\text { - Lack of investments (particularly foreign direct investments) }\end{array}$ \\
\hline & Associations & Weaknesses & - Lack of business association concerning forest industry \\
\hline GOVERNMENT & & Weaknesses & $\begin{array}{l}\text { - Lack of state policy which influence domestic forest sector } \\
\text { - Lack of subsidies and appropriate tax policy. } \\
\text { - Government is reluctant to provide financial assistance to export- } \\
\text { - Stated institutions does not penalize illegal companies } \\
\text { - Bureaucracy }\end{array}$ \\
\hline
\end{tabular}

\section{REFERENCES}

1. PORTER M 1990 The Competitive advantage of nations Houndmills, London

2. Ministry of agriculture, forestry and water economy 2006 Strategy for sustainable development of forestry in Republic of Macedonia. Available at: http://www.mzsv. gov.mk/strategija/54 (Accessed: 11 December 2008)

3. World Bank statistical review 2006 (Accessed 20 November 2008)

4. State Statistical office of Macedonia. Available at: http:// www.stat.gov.mk/statistiki.asp?ss=10.03\&rbs (Accessed: Accessed: 10 December 2008)

5. Forests police - Ministry of agriculture, forestry and water economy. Available at: http://www.mzsv.gov.mk/ index.php?lang =mk (Accessed: Accessed: 11 December 2008)

6. Public Enterprise "Makedonski šumi". Available at: http://mkdsumi.com.mk/en/ekz.asp (Accessed: 18 January 2009)

7. Food and agriculture organization of the United Nations
- FAOSTAT. Available at: www.fao.org (Accessed: 14 March 2009)

8. UNECE trade and timber division: timber bulletins. Available at: http://www.unece.org/timber/tcpubl.htm (Accessed: 11 December 2008)

9. UNIDO (United Nations Industrial development organization) Industrial Database. Available at: http://www. esds.ac.uk/international/access/access.asp (Accessed: 13 October 2008)

10. EU questionnaire, industry 2005. Available at: http:// www.sei.gov.mk/download/Questionnaire/3-15\%20-\%20 Industrial\%20policy.pdf (Accessed: 08 February 2009)

11. EUROSTAT: Forestry statistics pocketbook. Available at: http://epp.eurostat.ec.europa.eu/cache/ITY OFFPUB/ KS-76-06-322/EN/KS-76-06-322-EN.PDF (Accessed: 08 February 2009)

12. National bank of the Republic of Macedonia: financial reviews. Available at: http://www.nbrm.gov.mk/defaulten.asp?ItemID (Accessed: 08 March 2009) 